Article

\title{
Bank Processes and Revetment Erosion of a Large Lowland River: Case Study of the Lower Tisza River, Hungary
}

\author{
Tímea Kiss ${ }^{1, * \mathbb{C}}$, Gabriel J. Amissah ${ }^{1}$ and Károly Fiala ${ }^{2}$ \\ 1 Department of Physical Geography and Geoinformatics, University of Szeged, Egyetem u. 2-6, 6722 Szeged, \\ Hungary; gabbyjonad@yahoo.com \\ 2 Lower Tisza District Water Directorate, Stefánia 4,6720 Szeged, Hungary; fialak@ativizig.hu \\ * Correspondence: kisstimi@gmail.com; Tel.: +36-62-544545
}

Received: 18 April 2019; Accepted: 20 June 2019; Published: 25 June 2019

check for updates

\begin{abstract}
Stone and concrete revetments are widely constructed to control bank erosion and thus stabilize river banks. The consequences include accelerated erosion at unrevetted downstream channel sections and in-channel incision at revetted sections. The studied section of the Tisza River (Hungary) was revetted along $49 \%$ of its banks in the 20th century with stepped-block and placed-rock revetments. We therefore aimed (1) to study the effects of revetment constructions on channel processes and (2) to evaluate the state and collapse of revetments using a DEM of the channel and ADCP measurements. In the late 19th century, the river had an equilibrium meandering channel, with alternating eroding and aggrading banks. Currently, erosional processes dominate. Thus, $65 \%$ of the total channel length is affected by bank erosion. The revetments reduced the active lateral erosional processes only temporarily, as $58 \%$ of the revetments, mainly placed-rock, are already damaged. The flow characteristics at the revetted sections were found to depend on the rate and type of revetment collapse. Large pools developed in front of the revetments, playing an important role in initiating their erosion. The placed-rock revetments can collapse by slides or by stones falling into the pool one-by-one. In this case, a knickpoint develops, propagating upstream. Thus, the collapse and accelerated bank erosion also propagate upstream. The increased hazard created by the failure of the revetments requires the re-planning of bank stabilization practices.
\end{abstract}

Keywords: flow velocity; lower Tisza river; in-channel processes; revetment collapse; bank erosion

\section{Introduction}

The channel forms of alluvial rivers are altered temporally and spatially and influenced by changes in hydraulic and sediment load conditions [1-4]. As regime rivers are in dynamic equilibrium, they adjust their channel pattern, cross-sectional geometry, and slope in a quest to balance their ability to transport sediment and the available sediment load [5,6].

Bank and near-bank processes in alluvial channels are critical in-channel adjustments because they represent the channel response to energy dissipation mechanisms [3]. The rate of bank erosion is a function of the geometry and structure of the bank, the engineering properties of the bank material, the hydrological variability, the type and density of vegetation, the activity of animals, and the action of frost/thaw [7-9]. Bank erosion and subsequent lateral channel migration affect floodplain development [10,11], sediment input into the river [12,13], and the growth and development of meanders [14,15]. The flow within channels differs depending on the state of the banks, i.e., whether the free migration of the bend is possible, or whether the channel is constrained by engineering measures. Freely migrating channels are generally shallow and wide, with significantly lower mean velocities, bed 
shear stresses, and specific stream powers than other rivers [16]. Although bank erosion is a key driver of meander growth $[17,18]$, human interventions, including the construction of revetments, constrain the channel, resulting in reduced active bank processes [19].

Bank erosion has various forms, ranging from bank scour, which involves the removal and transportation of bank material by the flowing water, to bank sliding and toppling [14]. Bank erosion also poses threats to flood defense structures, transportation infrastructure, riparian lands, farms, and ecosystem patches. Bank stabilization measures, including the construction of revetments, are therefore necessary to mitigate these adverse effects [20,21].

The bank resistance of a river is altered significantly depending on the material used in bank stabilization [22]. Revetment types used in river bank stabilization include placed-rock revetment, gabion revetment, and block revetment, which is made of concrete. Although they serve as a control on channel width, the stabilized banks tend to increase the energy of the river by increasing flow velocity. The increased energy then has the potential to create accelerated channel erosion at downstream locations. Thus, they tend to cause in-channel incision, long-term bank instability due to under-mining of stabilized walls, and eventually, the collapse of revetted walls, localized channel widening, and deposition in downstream reaches [23,24].

The flow within a river describes the in-channel processes. An analysis of a large number of rivers showed that the mean velocity tends to increase downstream, although a previous hypothesis suggested a decreasing velocity due to decreasing slopes $[25,26]$. Because flow velocity variations and bed shear stress are responsible for the erosion of banks, in-channel bed erosion and sediment transport, knowledge of the velocity distribution within a channel is important in understanding in-channel processes and flow within bends [27-30]. Any modification of river banks affects the flow characteristics as it impacts the resistance offered to the flow through the channel. Depending on the material and type of stabilization, the shear stress developed at the bank varies due to friction between the flow and bank material. An increased velocity results in increased erosion and transportation with all other factors constant, while a decreased mean velocity results in increased deposition.

Across the globe, studies on various rivers have documented the changes that humans have impacted on rivers through regulations [26,31-33], including several rivers in Hungary [34-36]. River regulations generally modify the flow and sediment transport of a river channel, which affect both the channel form and river processes $[37,38]$. Therefore, knowledge of velocity variations within regulated rivers is important in understanding how these rivers respond to human impacts and environmental changes.

On the Lower Tisza River (Hungary), the regulation works, which included the construction of artificial flood protection levees and artificial cut-offs, resulted in intensive channel incision and lateral erosion $[23,36]$. The cut-offs accelerated the rate of bank erosion due to increased stream energy arising from higher channel slopes. The process accelerated bank migration and meander development, exposing the artificial levees to risk, as they were within 50-100 m of the channel at some sections. Therefore, revetments were constructed to impede lateral erosion and to protect the artificial levees. However, some revetments started to collapse. Coupled with increasing flood levels, the flood safety of the region is decreasing drastically, as renewed lateral erosion has the potential of destroying the existing flood defenses [39]. Therefore, to ascertain the state of bank processes, we aimed (1) to evaluate the spatiality of bank processes along the Lower Tisza River and (2) to compare the in-channel flow processes at revetted sections to the condition of the revetment and to the in-channel flow processes of a non-revetted section. To understand the processes taking place within the channel, we aimed to map the spatial dynamics of bank-forming processes and to reveal the morphological and velocity variations within the channel at sections with direct human impacts and those without.

\section{Study Area}

The Tisza River (Hungary) is a major tributary of the Danube. The mean discharge is 830 $\mathrm{m}^{3} / \mathrm{s}$ at Szeged, and the maximum and minimum discharges are $4348 \mathrm{~m}^{3} / \mathrm{s}$ (1932) and $58 \mathrm{~m}^{3} / \mathrm{s}(2013)$, 
respectively [39]. The Lower Tisza is a typical lowland river, as it has a low mean water slope $(1.5 \mathrm{~cm} / \mathrm{km})$ and relatively low flow velocities (mean velocity: $0.5 \mathrm{~m} / \mathrm{s}$ ). The river transports large amounts of fine-grained sandy and silty suspended sediments (18.7 million $\mathrm{t} / \mathrm{y})$, has a relatively low-quantity sandy bed load (9000 t/y), and has a clayey bed material [40-43].

The river regulation works on the Tisza began in the mid-19th century with the construction of artificial levees that disconnected the river from its wetlands, narrowing the active floodplain. Along the Lower Tisza, the originally 6-8 km-wide natural floodplain was confined by artificial levees to an average width of $1 \mathrm{~km}$. However, some sections of the floodplain are narrower than $380 \mathrm{~m}$ [44]. The narrow floodplain reduced the flood conductivity and increased the flood risk of the area considerably [45-47]. A total of 114 artificial cut-offs shortened the length of the Tisza River by $38 \%$, thus, the mean slope increased by ca. 30\% [23]. The original length of the studied Lower Tisza was $131 \mathrm{~km}$, and it was shortened to $90 \mathrm{~km}$ (by 30\%) by applying 12 artificial cut-offs. The construction of revetments and groins started in the late 19th century to stop lateral bank erosion at bends that were migrating too close to the artificial levees. Along the Lower Tisza, a total of $45 \mathrm{~km}$ of revetments (at 31 sections) were built since 1892, with most of them being constructed between the 1930s and 1960s [23]. The revetments were constructed by placing basalt blocks between the mean stage $(\mathrm{ca} .200 \mathrm{~cm}$ ) and the bottom of the side-slope of the river bed. A toe was created for the revetments using the same material, and a 1:1.5 slope was applied [48]. Since their construction, no further maintenance or repair has been made. The mean width of the channel decreased from $193 \mathrm{~m}$ at the end of the 19th century to $138 \mathrm{~m}$ today. Simultaneously, the mean depth increased from $12 \mathrm{~m}$ to $14 \mathrm{~m}[36,44]$. The narrowest sections $(\leq 100 \mathrm{~m})$ are mainly located at revetments.

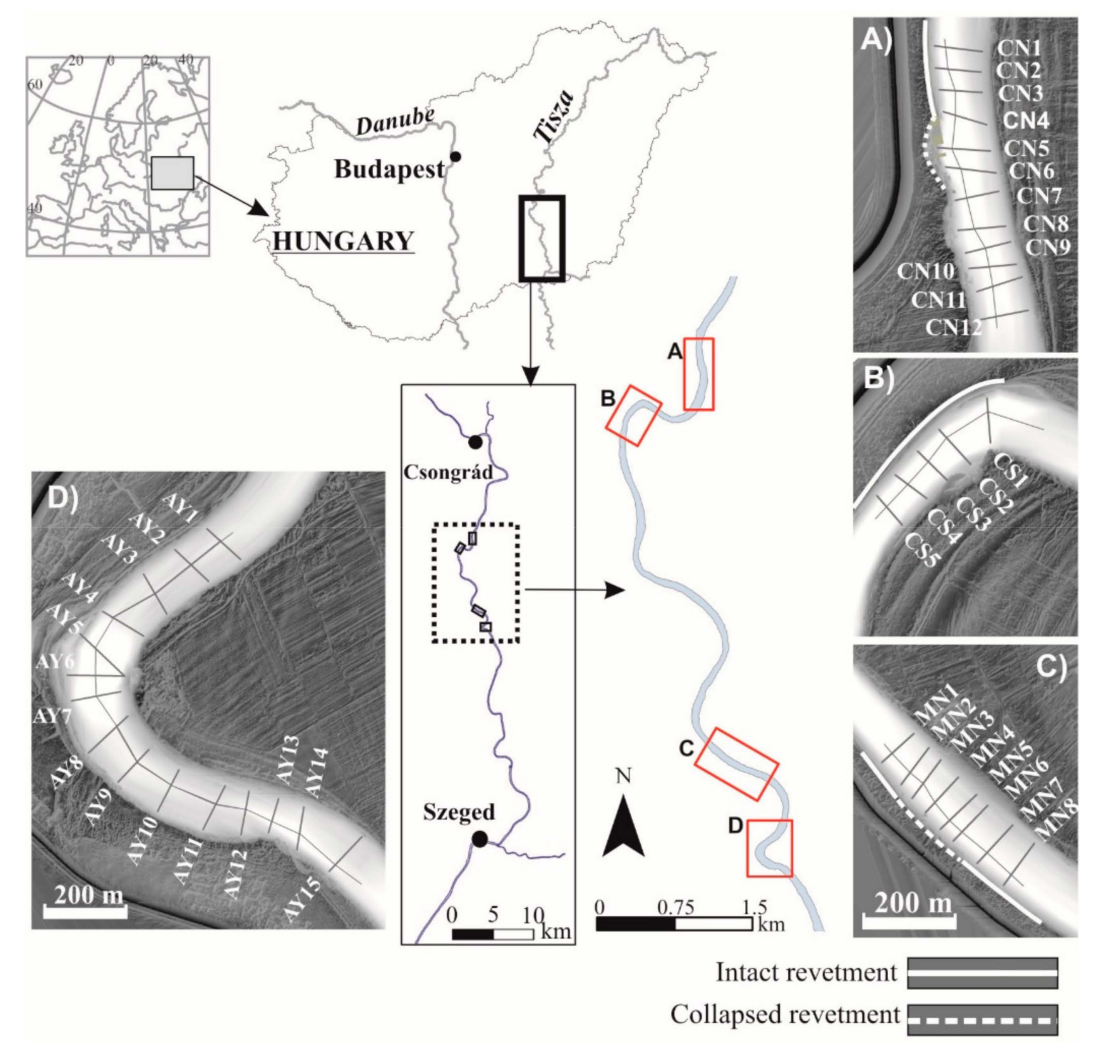

Figure 1. The banks of the Lower Tisza River (Hungary) were studied in detail between Csongrád and Szeged (78 km-long section). A detailed study was carried out at four sites along transects. (A): Csanytelek North; (B): Csanytelek South; (C): Mindszent; and (D): Ányás.

Our research was carried out at two spatial scales: surveys were made along a $78 \mathrm{~km}$-long reach of the Lower Tisza, and more detailed analyses were carried out at four sites (Figure 1), which differ in the type and date of revetment constructions. The northernmost site (CN: 227.4-226.6 f.km) is at a slightly 
sinuous section. Upstream of the site, an artificial cut-off was made accelerating bank erosion at the site. Thus, a $1080 \mathrm{~m}$-long placed-rock revetment was built in 1966 along the western bank. The study site includes the downstream end ( $300 \mathrm{~m}$ long) of the revetment and a non-revetted section. The last part of the revetment (ca. along a 110-m section) has already collapsed into the pool of the channel, and intensive lateral erosion $(1.2 \mathrm{~m} / \mathrm{y})$ has started, endangering the artificial levee just ca. $25 \mathrm{~m}$ from the bank line. The next site (CS: 224.7-224.1 f.km) is located in a meandering section. Although the revetment in this section was constructed in 1940, it is still intact, probably due to its different design (stepped-block revetment). The following site (M: 215.6-214.8 f.km) is also located in a bend. Here, the placed-rock revetment was constructed in 1910 to protect the artificial levee from lateral erosion, as the levee is just $25 \mathrm{~m}$ from the channel. The revetment started to erode by slip along its middle part (200 m length). However, its extent is not enough for the river to erode the banks directly behind it. The evolution of these revetted sections was compared to the evolution of an unconfined meander (A: 212.2-210.8 f.km), which was never directly affected by human activity. This meander migrates freely downstream $(1.7 \mathrm{~m} / \mathrm{y})$ with the same horizontal morphometric parameters and shape [49].

\section{Materials and Methods}

The bank morphology indicating the depositional and/or erosional forms along the Lower Tisza was surveyed from a boat at low stage. Six different bank types (Table 1) based on the particular active process were identified and mapped following the definitions of Lewin [14]. Simultaneously, the exact locations and state of revetments were surveyed. The results of this survey were compared to the existing database of the Lower Tisza Hydrological Directorate. Thus, the length of the eroded revetments was calculated. The location of actively accumulating bars was compared to the 1890 situation (Tisza Atlas, 1974).

Table 1. Characteristics of the identified and mapped bank-forming processes.

\begin{tabular}{ll}
\hline \multicolumn{1}{c}{ Bank Process } & \multicolumn{1}{c}{ Characteristics } \\
\hline active accumulation & The surface of point bars or side bar is covered by freshly deposited sand. \\
\hline failure & $\begin{array}{l}\text { Toppling failure resulting in a perpendicular scarp; usually fallen trees are in } \\
\text { the channel at the scarp base. }\end{array}$ \\
\hline slip & $\begin{array}{l}\text { Its back-slope is ca. } 45-60^{\circ} \text { steep. The bank is formed by mostly circular slips; } \\
\text { trees are standing in the water on the slumped material. }\end{array}$ \\
\hline failure combined with slips & $\begin{array}{l}\text { The back-slope of the failure is formed by subsequent slips, or the two processes } \\
\text { alternate closely next to each other. }\end{array}$ \\
\hline creeping & $\begin{array}{l}\left.\text { The bank has low slope (ca. } 20-40^{\circ}\right) \text {. The trees bend towards the channel. Their } \\
\text { exposed roots refer to slow bank scour and soil creeping. }\end{array}$ \\
\hline "form-free" section & Neither active erosion nor accumulation is identifiable. \\
\hline
\end{tabular}

At the four study sites, a detailed channel and flow velocity survey was conducted at a low stage. The survey was performed along transects spaced at approximately half of the channel width (40-105 m) and along the thalweg (Figure 1). The study employed a boat-mounted RiverRay ADCP (by Teledyne RD Instruments) with a GPS device. The obtained data were analyzed using WinRiver II software. Based on the measurements, the measured wetted width at the actual water level and the actual discharge were determined. The mean velocity for each transect was calculated from the arithmetic mean of velocity fields of bins at all measured depths. The specific stream power (stream power per specific width) was calculated by dividing the product of the discharge, local water slope within the study site, the density of water, and gravitational acceleration by the wetted width of each transect.

Within the same year, the local hydrological directorate (ATIVIZIG) surveyed the entire channel and the floodplain. To map the channel, transects with an approximately 100-m spacing were surveyed using a Sonar Mite Echo Sounder (by Ohmex Instruments), and the dataset was merged with airborne 
LiDAR data. The created DEM has a $\pm 10 \mathrm{~cm}$ vertical resolution. The channel morphology of the selected sites was studied based on this database along the transects of the velocity measurements. Based on the DEM, the bankfull levels of the channel cross-sections were determined, and the maximum channel depth $(\mathrm{m})$ and bankfull width $(\mathrm{m})$ were calculated.

\section{Results}

\subsection{Active Bank Processes of the Studied Reach}

Along the $78 \mathrm{~km}$-long surveyed reach of the Lower Tisza, most of the banks (65\%) were shaped by active erosion, $3 \%$ were characterized by accumulation, and $32 \%$ showed no identifiable active erosion or accumulation (Figure 2A). The most common bank erosional processes are creeping $(34 \%, 53 \mathrm{~km})$ and slips $(24 \%, 47.9 \mathrm{~km})$, though failures $(3.5 \%)$ and failures combined with slips (3.5\%) altogether form $10.9 \mathrm{~km}$-long banks. The most interesting result of the survey is that only 20 active bars exist in the area, with a total length of $4.7 \mathrm{~km}$, referring to the existence of few accumulation sections.

(A)

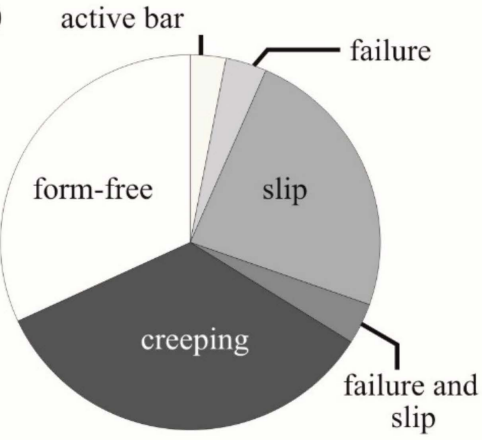

(B)

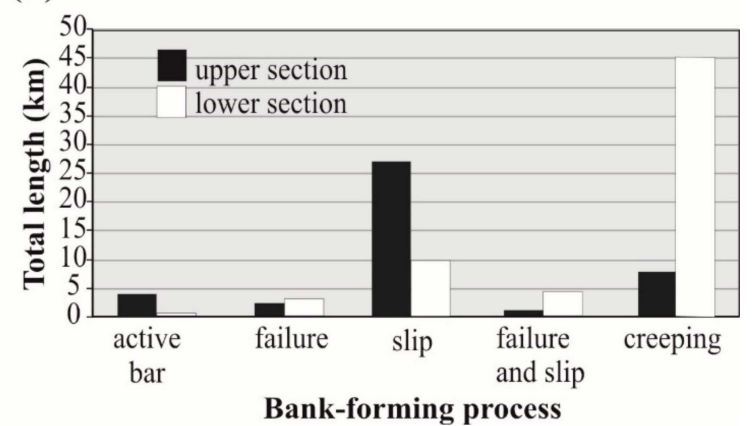

Figure 2. (A) Frequency of active bank processes, and (B) comparison of active processes along the upstream and downstream sections along the Lower Tisza.

The frequency of the various bank-forming processes of the upper meandering section (205-247 f.km) differs from the downstream (169-205 f.km) slightly sinuous section (Figure 2B). More intensive processes (e.g., slips, point bar development) form the upper meandering section, while creeping is the most common process in the lower sinuous section. Quite surprisingly, bank failures, especially slips, appear in similar length along the concave $(16 \mathrm{~km})$ and convex $(14.5 \mathrm{~km})$ sides of the channel (Figure 3). Slip is the characteristic erosional process of both point bars and convex banks, while failures are more abundant on concave, deeply incised banks.

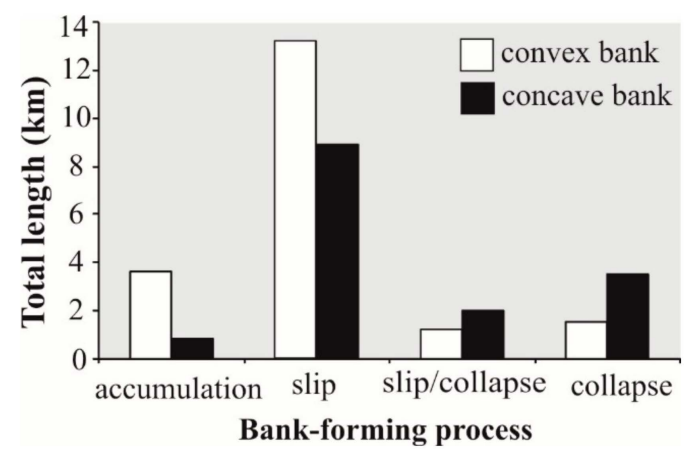

Figure 3. Bank-forming processes on the convex and concave banks of sinuous and meandering sections.

Active point bars developed in every bend and meander in the 1890s. Thus, they stretched along more than half of the entire studied reach at 47 locations (total length: $52.3 \mathrm{~km}$ ) covering 140 ha. Now, their number (20 in total), total area $(4 \mathrm{ha})$, and length $(4.7 \mathrm{~km})$ have decreased considerably. In the 
upstream meandering section of the Lower Tisza, 16 active bars remain, while in the downstream more straightened part, only four very short bar surfaces exist (Figure 4). Most of these bars are point bars developed on the convex side of the meanders, although some side bars also appear along concave or straight sections. All of these active bars also show erosion, as their margins are very steep (ca. 20-60 ), and slips often dissect them.

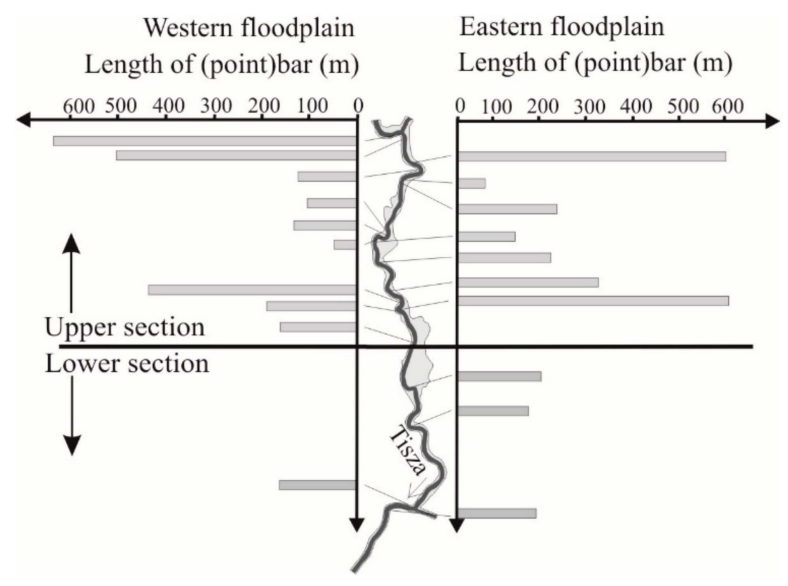

Figure 4. Location and length of active bars.

Along the surveyed length of the Lower Tisza, 31 revetments were built over a total length of $45 \mathrm{~km}$. Based on our field survey, 18 of them (58\%) are already damaged by erosion along $17.5 \mathrm{~km}$ in total. In most cases (76\%), the mass movements erode the downstream ends of the revetted banks, and the non-revetted downstream bank sections are also affected by failures and slips.

\subsection{Cross-Sectional and Longitudinal Profiles of the Selected Sites}

\subsubsection{Csanytelek North (CN)}

The channel at the Csanytelek North study site (Figure 5) was stabilized by a revetment on its western bank along $0.3 \mathrm{~km}$ (at cross-sections CN1-6) in 1966. Based on our recent survey, the downstream end of the revetment had collapsed (along $110 \mathrm{~m}$ at CN5-6). The downstream cross-sections (CN7-12) represented the channel without revetment but with intensive bank erosion (failures) along its western bank.
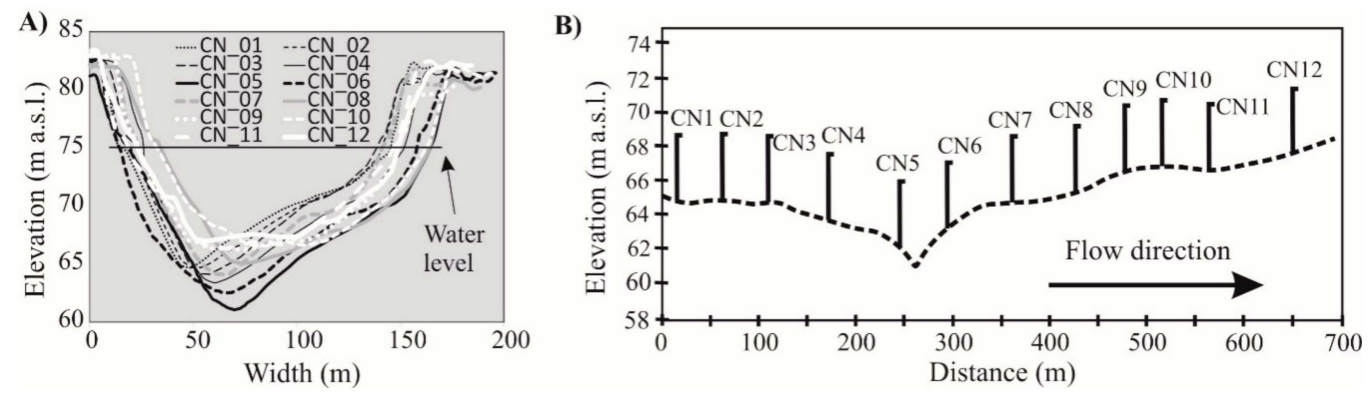

Figure 5. Cross-sectional channel profiles (A) and longitudinal thalweg profile (B) at the Csanytelek North study site.

The first four cross-sections (CN1-4) had a similar shape and width (140-150 m), as the revetment kept the western bank stable, and on the eastern bank, a side bar developed. The channel gradually became deeper (16.2-18.3 m), and the thalweg width increased downstream (CN1: $19 \mathrm{~m}$ compared to CN4: $40 \mathrm{~m}$ ). The thalweg was located ca. $45 \mathrm{~m}$ from the western bank at each cross-section, and its longitudinal profile was gently sloping $(0.8 \mathrm{~cm} / \mathrm{m})$ downstream. The cross-sectional parameters of the 
channel at the collapsed revetment (CN5-6) changed characteristically, as here the channel became deeper (18.5-21.0 m; by $14 \%$ ) and wider (bankfull width: $167-173 \mathrm{~m}$; by $15 \%$ ). The thalweg was ca. $65 \mathrm{~m}$ from the bank, but as the channel became deeper, its bottom also became wider $(50-60 \mathrm{~m})$. In front of the collapsed revetment, between the $\mathrm{CN} 5$ and $\mathrm{CN} 6$ cross-sections, a large and deep pool developed, toward which the thalweg sharply sloped $(3.2 \mathrm{~cm} / \mathrm{m})$. However, at CN6, the thalweg started to ascend $(6.3 \mathrm{~cm} / \mathrm{m})$. The channel downstream of the collapsed revetments (CN7-12) gradually became shallower (max. bankfull depth: 13.4-17.5 m) and narrower (140-160 m). The changes in width were related to the active bank-forming processes, as greater width was related to bank failures and slides. The channel became the widest $(170 \mathrm{~m})$ and shallowest $(15.3 \mathrm{~m})$ at the last cross-section (CN12). The thalweg gradually shifted to the middle of the channel, and the channel shape became more symmetrical. In the meantime, the thalweg became shallower by $7.2 \mathrm{~m}$ (average slope: $1.6 \mathrm{~cm} / \mathrm{m}$ ), referring to the development of a riffle downstream.

\subsubsection{Csanytelek South (CS)}

The next study area is located in a meander where the stepped-block revetment was built in 1940 along the entire concave western bank (Figure 6). A point bar developed along the convex bank. However, slips already dissected its surface. The first channel cross-section (CS1) was the shallowest (bankfull depth: $17.8 \mathrm{~m}$ ) cross-section of the study site despite its location in a small pool, and from here, the channel became even deeper. Here, the channel was $147 \mathrm{~m}$ wide, and the thalweg was located $50 \mathrm{~m}$ from the western bank with a high slope $(\mathrm{ca} .6 \mathrm{~cm} / \mathrm{m})$. Although this cross-section was located at the apex of the meander where the point bar was located, it had a unique cross-sectional shape: The point bar on the eastern side was sliding, thus, instead of having a gentle slope, an almost perpendicular wall developed, representing the front of the slumped material. The erosion of the point bar was the most intensive at the next cross-section (CS2), where the channel was the widest $(173 \mathrm{~m})$ and deepest $(22 \mathrm{~m})$ at the study site. The thalweg was farthest $(\mathrm{ca} .70 \mathrm{~m})$ from the western bank, and its slope was $9 \mathrm{~cm} / \mathrm{m}$. The following downstream cross-sections (CS3-5) referred to a more uniform channel (bankfull width: 130-132 m; bankfull depth: 18.3-19.2 m). The thalweg migrated toward the western bank ( $50 \mathrm{~m}$ from the bank) and had a gentler slope (ca. $2 \mathrm{~cm} / \mathrm{m}$ ).
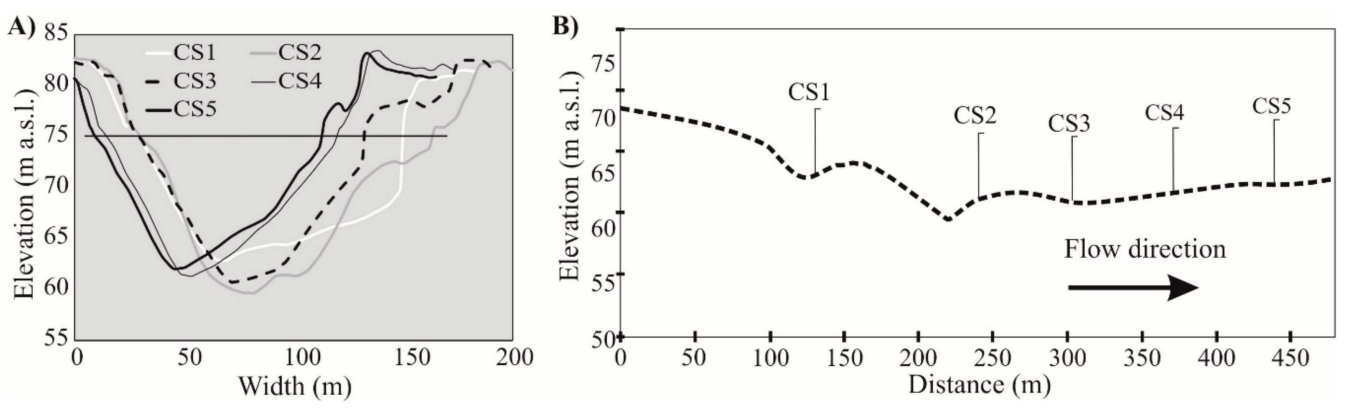

Figure 6. Cross-sectional channel profiles (A) and longitudinal thalweg profile (B) at the Csanytelek South study site.

\subsubsection{Mindszent (MT)}

The revetment at the Mindszent study site (Figure 7) was built in 1910 along the entire length of the western bank, but has already started to collapse by sliding. On the opposite, convex bank a point bar exists. Here, the cross-sections were very similar to each other: The thalweg was skewed toward the revetted western bank (ca. $50 \mathrm{~m}$ ). The first two cross-sections (MT1-2), upstream of the point bar, were the narrowest, although their bankfull width increased downstream $(139 \mathrm{~m}$ and $155 \mathrm{~m}$, respectively). Likewise, the bankfull depth increased downstream ( $15.2 \mathrm{~m}$ and $16.0 \mathrm{~m})$. The middle cross-sections (MT3-6) crossing the point bar along the eastern bank had similar parameters (bankfull width: 174-181 m, and bankfull depth: 15.2-16.5 m). The point bar on the eastern bank had a similar brink-line height (above $81 \mathrm{~m}$ a.s.l) as the opposite bank, but while the concave bank had a steep slope 
(ca. $\left.45^{\circ}\right)$, the point bar had a considerably lower slope $\left(14^{\circ}\right)$. Downstream of the point bar, the channel (MT7-8) became narrower (165 $\mathrm{m}$ and $175 \mathrm{~m})$ and shallower $(14.8 \mathrm{~m}$ and $14.3 \mathrm{~m})$ again.
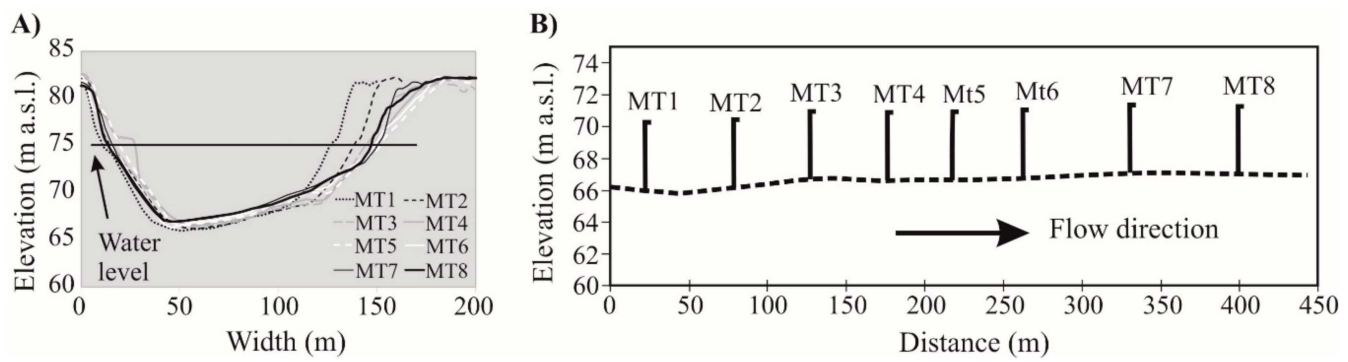

Figure 7. Cross-sectional channel profiles (A) and longitudinal thalweg profile (B) at the Mindszent study site.

\subsection{4. Ányás (AY)}

The Ányás study site represents a free meander without any direct human intervention. Thus, all cross-sections (AY1-15) represented the natural channel morphology with a complex pattern of lateral erosion and active accumulation (Figure 8). The first four cross-sections (AY1-4) referred to a riffle located at the inflection zone between two meanders (bankfull width: 153-203 m; bankfull depth: 10.3-11.8 m). Along this section on the western bank, the formation of a side bar indicates aggradation, while on the eastern bank, slips referred to active erosion. The channel had relatively symmetrical cross-sections, as the thalweg was located in the middle of the channel (slope: $0.3 \mathrm{~cm} / \mathrm{m}$ ). Downstream of the riffle, a sharp transition into a pool was observed. Within this pool, the cross-sections (AY5-7) remained symmetrical, but their bankfull width (200-240 m) and bankfull depth (12-15 m) increased. Here, the thalweg was slightly skewed to the western bank (ca. $80 \mathrm{~m}$ from the bank), although the bottom of the channel remained quite uniform. The slope of the thalweg in this pool increased $(3 \mathrm{~cm} / \mathrm{m})$ with a knick-point upstream of cross-section AY5. Downstream of the pool another, ca. $400 \mathrm{~m}$-long riffle developed (AY8-11). Here, the channel gradually became narrower (bankfull width: 187-170 m) and shallower (bankfull depth: 13.5-11.0 m). The cross-section AY8 represented a transitional character between the previous pool and the next riffle (bankfull width: $188 \mathrm{~m}$; and bankfull depth: $13.5 \mathrm{~m}$ ). On the western (concave) side of this riffle, the previous surveys [49] indicated intensive bank erosion (ca. $1.2 \mathrm{~m} / \mathrm{y}$ ) with increasing intensity downstream as the slips were replaced by total bank collapse. The point bar on the opposite eastern bank actively accumulated, compensating for the erosion of the other side, thus keeping the channel size relatively unchanged. There was a gradual thalweg shift towards the eastern bank in this riffle section, while at the same time, the elevation of the thalweg increased by $1.2 \mathrm{~m}$ (slope: $0.4 \mathrm{~cm} / \mathrm{m}$ ). Downstream of this riffle, another pool developed (AY12-15) with a relatively narrow bankfull width (135-175 m) and deep channel (bankfull depth: 13.7-15.2 m). The thalweg migrated toward the western bank within this pool and had a relatively gentle slope $(1.4 \mathrm{~cm} / \mathrm{m})$ compared to the larger pool upstream.
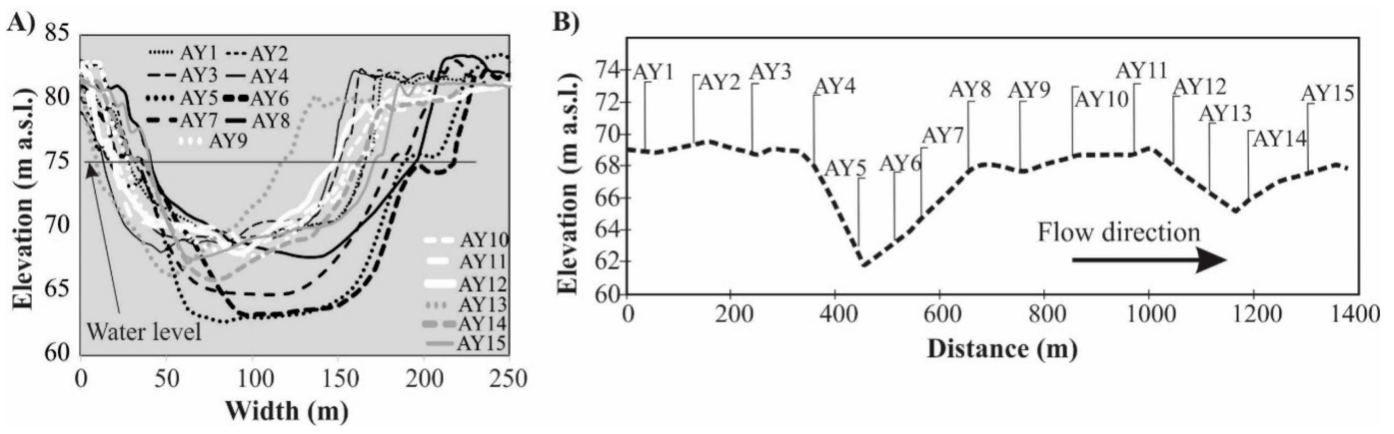

Figure 8. Cross-sectional channel profiles (A) and longitudinal thalweg profile (B) at the Ányás study site. 


\subsection{Flow Conditions at the Study Sites}

\subsubsection{Velocity Conditions}

Due to the proximity of the Csanytelek North and Csanytelek South sites, the mean velocities at the two sites were similar (Figure 9). The Csanytelek South represented the lowest mean velocity (CS: $0.31 \mathrm{~m} / \mathrm{s})$ of all four sites, while the free meander of Ányás had the highest mean velocity $(0.41 \mathrm{~m} / \mathrm{s})$. Within the individual sites, the mean velocities of transects at Mindszent had the least range $(6.3 \%$ and $0.02 \mathrm{~m} / \mathrm{s}$ ) in comparison to the other transects $(\mathrm{CN}: 14.1 \%$ and $0.05 \mathrm{~m} / \mathrm{s} ; \mathrm{CS}: 13.1 \%$ and $0.04 \mathrm{~m} / \mathrm{s}$; AY: $55.7 \%$ and $0.18 \mathrm{~m} / \mathrm{s}$ ). At Csanytelek North, the range of mean velocities within the intact revetted section was only $3 \%$. At the collapsed revetted section, the range increased to $6 \%$, however, at the non-revetted section, it was as high as $13 \%$. Although the Csanytelek South site was fully revetted, the mean velocity differed by up to $13 \%$, with the CS1 transect accounting for more than half of the variation. At the Mindszent site, the velocity variations were similar (6.3\%), although the middle four transects (at the point bar and the sliding revetment) had the highest mean velocities $(0.35-0.36 \mathrm{~m} / \mathrm{s})$ within the site. The highest mean velocities of all study sites were measured at the Ányás site, where two-thirds of the transects had high mean velocities $(\geq 0.40 \mathrm{~m} / \mathrm{s})$ and only one transect had a similar low velocity $(\leq 0.35 \mathrm{~m} / \mathrm{s})$ as the other three sites.

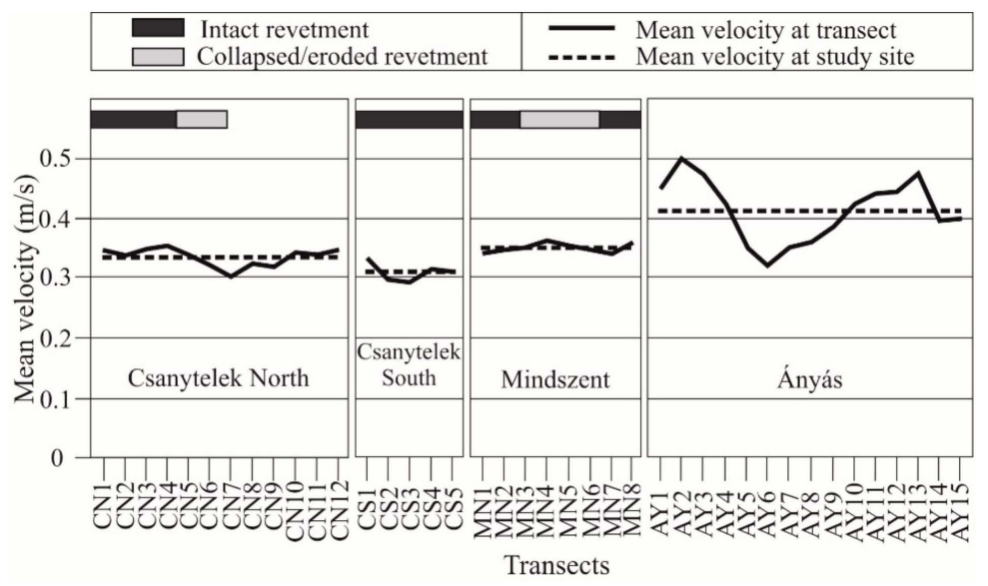

Figure 9. Characteristic velocity values at the study sites and the locations of revetments on the western bank.

The areal distribution of velocity fields indicated that at the revetted study sites, two-thirds of the velocity fields belonged to the range of $0.2-0.4 \mathrm{~m} / \mathrm{s}$, while at the freely meandering Ányás site, they belonged to a higher range $(0.3-0.6 \mathrm{~m} / \mathrm{s})$. At Csanytelek North, the intact revetment transects (CN1-4) were characterized by relatively similar velocity distributions, as ca. $90 \%$ of the wetted area had $0.2-0.5 \mathrm{~m} / \mathrm{s}$ velocity fields. Along the collapsed revetment and its immediate downstream sections (CN5-7), velocity fields were similar, but the same range $(0.2-0.5 \mathrm{~m} / \mathrm{s})$ occupied less than $80 \%$ of the wetted area, as the area of the very low $(\leq 0.2 \mathrm{~m} / \mathrm{s})$ velocity fields increased. Downstream of the collapsed revetment (CN8-12), the area of the $0.2-0.5 \mathrm{~m} / \mathrm{s}$ velocity fields gradually increased (84-93\%) again. Along the intact revetment at Csanytelek South, a gradual areal increase in the $0.2-0.5 \mathrm{~m} / \mathrm{s}$ velocity fields was detected in the downstream direction (from $60 \%$ to $91 \%$ ). Although the Mindszent site had collapsed revetment and a point bar within its middle section, the distribution of characteristic velocity fields (0.2-0.5 m/s) was fairly uniform (ca. 90\%) throughout the studied section. At the free meander of the Ányás site, the velocity conditions were the most variable related to the pool and riffle series. Within the first riffle section (AY1-4), unlike the other study sites, the $0.4-0.5 \mathrm{~m} / \mathrm{s}$ velocity field had the highest frequency (20-32\%). In the next pool section (AY5-6), lower velocity fields $(0.2-0.3 \mathrm{~m} / \mathrm{s})$ occupied the highest area (28-35\%). Very high-velocity fields $(>0.6 \mathrm{~m} / \mathrm{s})$ were recorded in the second riffle section (4-23\%), and these high-velocity fields remained even in the last pool section (2-12\%). 


\subsubsection{Discharge and Specific Stream Power}

The Csanytelek North and Csanytelek South sites are located close to each other (ca. $2 \mathrm{~km}$ apart). Therefore, they had similar discharges (184-216 $\left.\mathrm{m}^{3} / \mathrm{s}\right)$, although their wetted widths differed $(\mathrm{CN}$ : 82.2-125.1 m; CS: 87.4-98.6 m). At Csanytelek North, the highest discharge was recorded at the end of the collapsed revetment (CN5). At Csanytelek South, the wetted widths were similar due to the existence of a revetment, but the discharges varied relating to the morphological conditions, as the lowest discharge $\left(185 \mathrm{~m}^{3} / \mathrm{s}\right)$ was measured at the end of the point bar (CS3), and the highest value $\left(215 \mathrm{~m}^{3} / \mathrm{s}\right)$ was recorded at the downstream riffle (CS5). At Mindszent, although part of the revetment along the western bank collapsed, the discharge characteristics of the transects were very similar (204-214 $\left.\mathrm{m}^{3} / \mathrm{s}\right)$, having the lowest range for all the studied sites. The Ányás site had the most variable parameters, characterized by high ranges in both wetted width $(89.5-154.6 \mathrm{~m})$ and discharge (193-230 $\left.\mathrm{m}^{3} / \mathrm{s}\right)$.

Although the measurements were carried out at low stage and discharges were generally similar, the specific stream power was the highest at those sites where the revetments were already collapsing (Csanytelek North and Mindszent), while the meander with the stabile revetment (Csanytelek South) and the free meander at Ányás were characterized by significantly lower specific stream power (Figure 10).

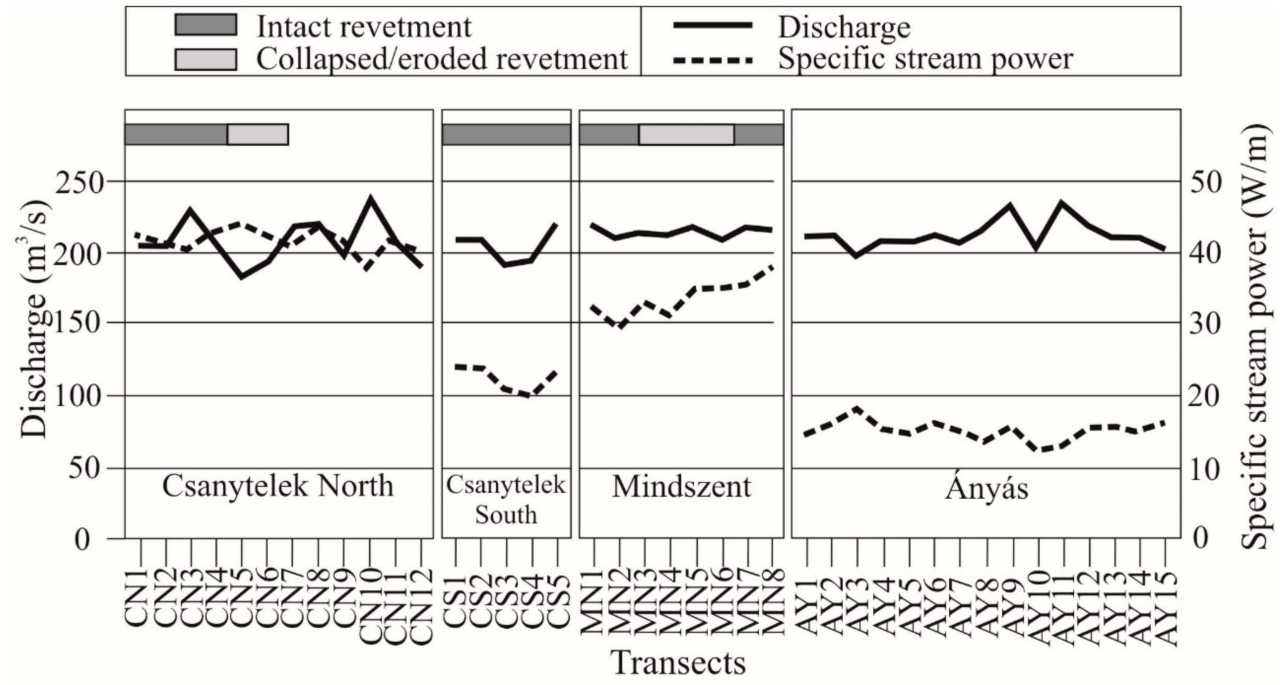

Figure 10. Variation of specific stream power and discharge values along the studied sections showing locations of revetments on the right bank.

\subsection{Influence of Channel Morphology and Revetments on Velocity Fields}

\subsubsection{Csanytelek North $(\mathrm{CN})$}

The velocity distribution of the flow is closely related to channel morphology and bank characteristics. The upper transects (CN1-4) along the intact revetment had similar morphological characteristics. However, the velocity distribution of the last $(\mathrm{CN} 4)$ transect was different (Figure 11A). The CN1-4 transects had relatively high mean velocities $(0.34-0.35 \mathrm{~m} / \mathrm{s})$. The lowest flow velocity was measured above the side bar, while the highest velocity fields $(0.4-0.6 \mathrm{~m} / \mathrm{s})$ developed within a ca. $40 \mathrm{~m}$-wide zone between the thalweg and the intact revetment. At the CN4 transect, the highest velocity fields $(0.4-0.6 \mathrm{~m} / \mathrm{s})$ occupied a wider zone $(\mathrm{ca} .50 \mathrm{~m})$, and near the bottom, relatively high velocities $(0.6 \mathrm{~m} / \mathrm{s})$ developed.

In the frontal pool at the collapsed revetment, the flow velocity dropped almost to $0 \mathrm{~m} / \mathrm{s}$ (the measurement was made at low stage). Thus, the mean velocity of these transects dropped to $0.32 \mathrm{~m} / \mathrm{s}$ (by $8.5 \%$ ). The quite low flow velocity was connected to the increase in the wetted area as the result of bank failures and the development of the deep pool. These data characterize not only the collapsed revetment (CN5-6) but also a short section downstream of it (CN7). 
In the downstream riffle transects (CN8-12), the mean velocity increased gradually from $0.32 \mathrm{~m} / \mathrm{s}$ to $0.34 \mathrm{~m} / \mathrm{s}$ as a response to decreasing width and wetted area, despite the elevating bottom. At the top of the riffle, the velocity distribution of the channel became more uniform in the symmetrical channel.
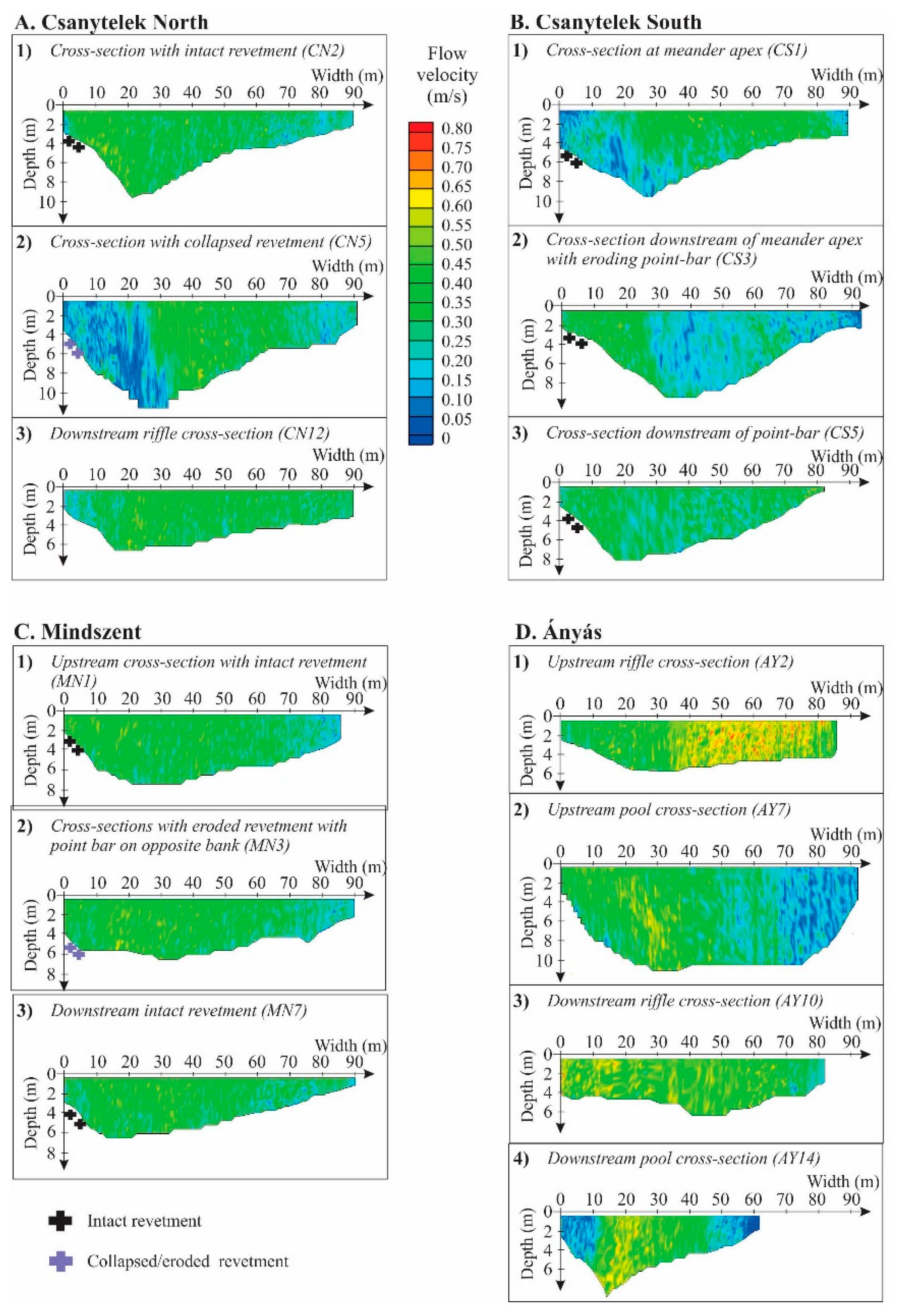

Figure 11. Typical velocity fields of the morphological units of the study sites at (A) Csanytelek North, (B) Csanytelek South, (C) Mindszent, and (D) Ányás. The existence and state of the revetment is indicated by crosses.

\subsubsection{Csanytelek South (CS)}

The Csanytelek South study site had the lowest mean velocity $(0.31 \mathrm{~m} / \mathrm{s})$ among all the study sites, but showed marked differences (Figure 11B). At the apex of the meander (CS1), the highest flow velocity developed from the site to the downstream section, the bottom of the channel descended, and almost $0 \mathrm{~m} / \mathrm{s}$ velocity fields were observed along the banks and at the thalweg. The following downstream transects (CS2-3) had relatively high velocities along the revetted bank, but in the pool and above the point bar, low-velocity fields appeared. As the pool terminated, the last two transects (CS4-5) downstream exhibited uniform mean velocities.

\subsubsection{Mindszent (MT)}

The flow velocity distribution in the Mindszent study site was mostly uniform (Figure 11C), as the cross-sectional channel profiles and the longitudinal thalweg profile represented only minor changes. The existence of intact (MT1-2 and MT7-8) and slipped revetments (MT3-6) did not affect the velocity fields considerably as similar velocity fields developed along the western bank. 


\subsection{4. Ányás (AY)}

At this free meander, the alternating riffle-pool sequence and the various bank processes had a considerable effect on the flow velocity distribution (Figure 11D). In the riffle sections and in the relatively shallow downstream pool, the $0.4-0.5 \mathrm{~m} / \mathrm{s}$ velocity fields were dominant. However, in the deep upstream pool, low-velocity fields $(0.3-0.4 \mathrm{~m} / \mathrm{s})$ were characteristic.

Within the upstream riffle (AY1-3), the high-velocity fields $(0.5-0.7 \mathrm{~m} / \mathrm{s})$ skewed toward the eastern bank. Thus, it eroded intensively $(1.0 \mathrm{~m} / \mathrm{y})$, while along the western bank, a side bar developed under the lower velocity fields. However, transect AY4 had transitional characteristics, as its morphology referred to a riffle, although its velocity fields were as those of a pool.

In the next pool, the first transect (AY5) had very low velocities along its banks, but other parts of the pool were characterized by higher velocities $(0.4-0.6 \mathrm{~m} / \mathrm{s})$ due to the development of a large whirlpool. At the exit of the pool (AY6-7), the flow distribution became uniform, and high-velocity fields $(0.5-0.7 \mathrm{~m} / \mathrm{s})$ developed in the ascending thalweg zone.

As the pool transitioned into the next riffle, velocities increased as the channel area decreased. At this riffle (AY8-11), high-velocity fields $(0.5-0.6 \mathrm{~m} / \mathrm{s})$ developed close to the western bank as the thalweg was skewed to it.

These high-velocity fields remained in the last pool (AY12-15), which was shallower than the upstream pool. Here, in front of the western bank, high-flow-velocity fields $(0.5-0.8 \mathrm{~m} / \mathrm{s})$ evolved, supporting intensive lateral erosion $(1.2 \mathrm{~m} / \mathrm{y})$. The velocity fields at the western bank decreased at the last two transects (AY14-15) as the high-velocity fields and the thalweg shifted toward the middle of the channel.

\section{Discussion}

The upstream section of the Lower Tisza (205-247 f.km) is characterized by more active bank processes than the downstream section (169-205 f.km). This difference could be explained by the greater sinuosity (1.48) of the upstream section; thus, the thalweg shifts closer to the concave banks. Therefore, the conditions (greater channel depth combined with steep slopes of the stratified channel material) are more favorable for failures and slips on the concave banks and for point bar development on the convex ones. In contrast, the downstream part of the studied reach is less sinuous (1.24). Thus, the thalweg runs in the middle of the channel, making the active erosion of the banks limited. Along this downstream section, the banks could be eroded by scouring during high stages and by creeping during low stages. Therefore, along this less-sinuous section, bank failures are located along very narrow channel segments, and the development of bars is not very common. Along the entire Lower Tisza, the total length and area of the point bars decreased radically during the past century. Only a few bars remained (e.g., at the Ányás site), and they experienced net erosion. The abundance of slips, especially on point bars, could be explained by the incision of the channel $[36,45]$, which provides steep slopes during low stages when the 3-9 m-high banks lose their lateral support. In addition, the sandy-clayey layers of the bars incline towards the channel (especially at point bars). Thus, the groundwater at low stages flows toward the channel, providing suitable conditions for slips. The concave sides of the meanders also have high banks as a result of thalweg incision; therefore, deep-rooted slips and/or failures form the banks. The high abundance of erosional forms refers to channel metamorphosis of the Tisza River: The 19th century meandering channel lost its sinuosity as the result of artificial cut-offs. However, currently, the channel has started to incise.

The incision and accelerated bank erosion started immediately after channel regulations [23]. Therefore, revetments were built to protect the artificial levees, mostly before 1960 ( $82 \%$ of revetments). After their construction, the active bank erosion terminated. However, the incision became more intensive as the channel began to adjust itself to the construction of the revetments [23,36]. The density of the revetments (mean: $0.50 \mathrm{~km} / \mathrm{km}$ ) is not uniform within the Lower Tisza, as the upper and more sinuous reach has a higher revetment density $(0.64 \mathrm{~km} / \mathrm{km})$, especially along the western bank $(60 \%)$, where an artificial levee was built close to the channel, and only $40 \%$ of the revetments are along 
the eastern bank. In the upper reach, more revetments started to collapse because the high sinuosity provided favorable conditions for natural channel adjustment, and thus, the erosion of the revetments.

According to our results, the type of revetment is a significant factor in revetment stability, but revetment age is not. Most of the collapsed revetments are placed-rock revetments (e.g., CN and MT sites), thus, the incision of the channel can initiate the removal of the stones one-by-one. In contrast, if the revetment has a stepped-block design (stones placed within a concrete frame), it can prevent the erosion of single rocks for a longer time (e.g., CS site). However, in such cases, the energy of the flow is deflected away from the revetted bank to the opposite bank, initiating the erosion of point bars, though here, under natural conditions, low flow velocities and energy are characteristic [50].

The placed-rock revetments erode in two different ways, as indicated by our conceptual model (Figure 12). High velocities generated near the revetment along the concave bank accelerate vertical erosion. Thus, the channel became deeper by $1-2 \mathrm{~m}$ after the river regulations were implemented [36], providing favorable conditions for mass movements along long revetted sections (e.g., at MT) or the collapse of the stones one-by-one (e.g., at $\mathrm{CN}$ ). In the latter case, the downstream end of a placed-rock revetment erodes first as a result of the co-existence of the following factors: (1) The thalweg is skewed close to the revetted bank, (2) the smooth upstream revetment section has velocity acceleration, and (3) the flow has higher erodibility. In this way, although the revetment protects the bank from lateral erosion, immediately at its end the flow has high erosivity, enhancing vertical and lateral channel erosion immediately downstream of the revetment. Therefore, here, the non-revetted bank is formed by high-intensity failures and slides, and a deep pool develops. However, the erosional front migrates upstream. At first, the skewed thalweg probably increases the size of the pool, providing suitable conditions for the collapse of the revetment rocks one-by-one. Later, as the rocks fall into greater depth, they allow intensive lateral erosion of the formerly protected bank. Based on the longitudinal profile of the channel bottom and the bankline, a knickpoint can be identified: Downstream of this knickpoint, both the vertical and lateral erosion accelerated, creating a small pool at the end of the revetment. This knick-point propagates upstream, and newer parts of the revetment will therefore collapse until the entire revetment is destroyed.
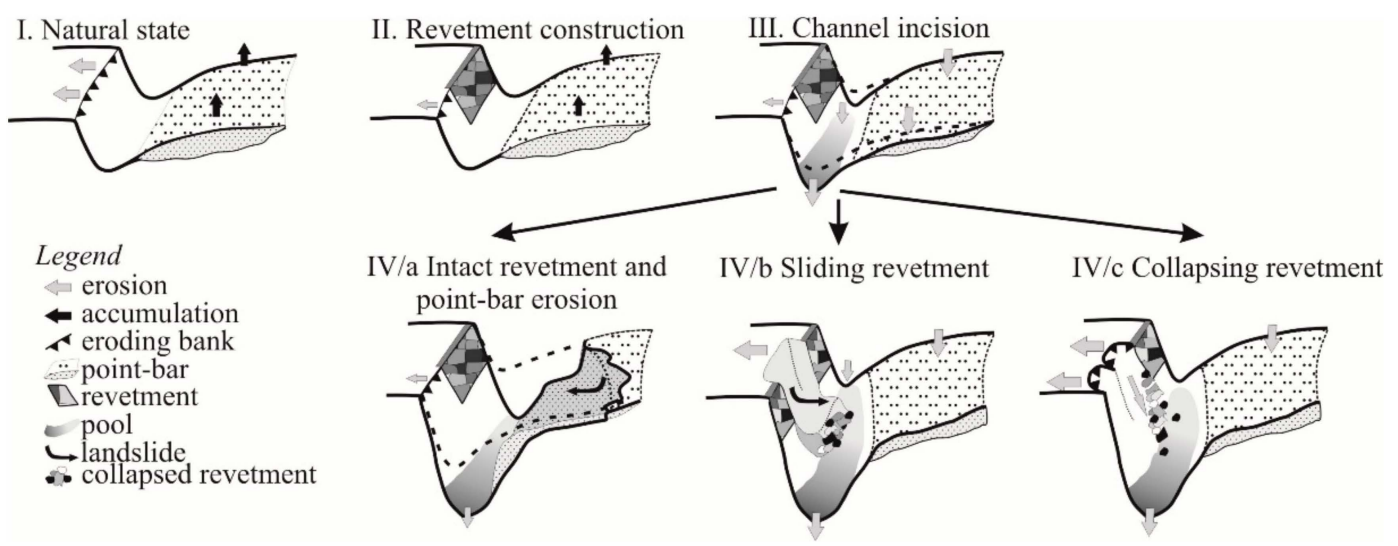

Figure 12. Conceptual model of bank erosion and revetment collapse in the Lower Tisza.

The rate of bank erosion along the collapsed revetments can be as high as 3-6 m/y [49]. Therefore, the artificial levee sections within $25-50 \mathrm{~m}$ distance will be endangered by lateral erosion within the next 8-15 years, directly risking altogether $7.7 \mathrm{~km}$-long levee sections in the Lower Tisza region. The western artificial levee is at a higher risk, as it is closer to the active channel. In addition, on the western protected floodplain, the settlements are located closer to the artificial levee and the river, which further increases the hazard.

Our survey proved that the construction of revetments makes the channel morphology more homogeneous and unifies the flow conditions at low stages. The studied non-revetted section (AY) of the Lower Tisza displayed the most variability in flow velocity, morphological processes, and forms, as 
here the riffle-pool series is combined with the development of various bars and active bank-erosion processes. At the riffles, high-velocity fields developed, while in the pools, lower velocities developed, as was expected in a riffle-pool sequence [51-53]. High-velocity fields skewed to the bank, resulting in active bank-erosion processes. The comparison of the riffles in the revetted (CN and CS) and in the freely meandering sections (AY) shows that the riffles are deeper and narrower in the revetted channel. Therefore, lower velocity fields developed at the low stage.

The future development of the revetments can be predicted from the specific stream power calculated for the study areas. The lowest stream power characterizes the freely developing meander (AY: 11-17 W/m), while high values (CS: 19-23 W/m) were measured at the intact, well-designed revetment with an intensively eroding point bar, and even higher values were observed at the sliding revetment with non-eroding banklines (MT: $(28-37 \mathrm{~W} / \mathrm{m})$. Finally, the highest values were displayed at the intensively eroding revetment with a very high bank-erosion rate $(\mathrm{CN}: 35-46 \mathrm{~W} / \mathrm{m})$. These differences in stream power suggest that the erosion will continue along the already eroding revetments, and at the other sites, the energy of the flow is dissipated by the channel forms and active processes along the non-revetted banks [16]. However, the higher specific stream power values of the revetted sections suggest that slow erosion will occur in the future.

\section{Conclusions}

The channel pattern of the Tisza has changed in response to channel regulations, and the originally meandering equilibrium river transformed into a meandering-incising one [23,50]. This channel metamorphosis is indicated by the abundance of erosional bank processes, the disappearance of bars, the slip of point bars, and the collapse of revetments. Similar erosional processes are widespread on rivers, and they usually tend to decrease flood hazards as the flood frequency decreases [54]. However, in our case, due to the collapse of the revetments, the artificial levees are endangered by lateral erosion, which increases the possibility of levee failure and thus increases the risk of flood hazards.

In the studied lowland section of the river, placed-rock and stepped-block types of revetments were built. Our survey suggests that incision within the channel can accelerate the erosion of the placed-rock type more, as the rocks can fall into the over-deepened pools one-by-one. Therefore, in similar fluvial settings (e.g., low water slope, erodible bed material), the application of the stepped-block revetment type is suggested. The erosion of the placed-rock revetments can take place in two different ways. Gravitational slides may destroy long revetment sections at the apex of bends, however, the slumped material can protect the bank from lateral erosion for a while. On the other hand, if the downstream end of a revetment is eroded by scouring, the process propagates upstream, destroying longer and longer revetment sections and supporting intensive lateral bank erosion on the unprotected sections.

In the study area, $58 \%$ of the revetments are already eroded. Therefore, we suggest reviewing the existing bank-protection practice in similar environments: (1) in the case of new revetment constructions, the revetments should be extended downstream toward the inflection zone; thus, the end will be farther from the high erosivity velocity fields; (2) a strengthened stepped-block-type revetment should be applied; and (3) in some narrow and sharp bends, the replacement of artificial levee sections could be considered; or (4) the thalweg could be diverted by applying groins.

However, our study proved that the construction of revetments has had drastic long-term effects on bank processes. As revetments are relatively expensive measures to implement and maintain, their presence, as part of the entire channelization scheme, seems to have caused a range of unfavorable processes, such as incision, enhanced lateral erosion at the collapsed revetments, and the evacuation of sediment from this part of the river. Even along the unrevetted sections, erosional processes became dominant, as the transferred stream energy initiated active bank erosion downstream of the revetments. Additionally, the aggressive front of the revetment erosion propagates upstream. In this way, the entire system can incise even more by accelerating the erosion around built-in structures (e.g., bridge piers, groins) and by lowering low stages, contributing to the lowering groundwater level and making water withdrawal difficult and expensive. 
Author Contributions: Research conceptualization and supervision and a portion of the analysis were done by T.K.; the methodology was established and implemented by K.F.; and data acquisition and a portion of the analysis was done by G.J.A.

Funding: The research was supported by the Stipendium Hungaricum Programme and the Hungarian Research Foundation (OTKA 119193).

Acknowledgments: ADCP data were recorded with the aid of the Water Directorate of the Lower Tisza District (ATIVIZIG). We are grateful to R. Horváth and J. Nagy (University of Szeged), as well as T. Seres and R. Balog (ATIVIZIG), for their help provided during the surveys.

Conflicts of Interest: The authors declare no conflict of interest.

\section{References}

1. Thorne, C.R.; Tovey, N.K. Stability of composite river banks. Earth Surf. Process. Landf. 1981, 6, 469-484. [CrossRef]

2. Smith, L.M.; Winkley, B.R. The response of the Lower Mississippi River to river engineering. Eng. Geol. 1996, 45, 433-455. [CrossRef]

3. Simon, A.; Curini, A.; Darby, S.E.; Langendoen, E.J. Bank and near-bank processes in an incised channel. Geomorphology 2000, 35, 193-217. [CrossRef]

4. Knighton, D. Fluvial Forms and Processes: A New Perspective, 2nd ed.; Routledge: New York, NY, USA, 2004; pp. 151-260.

5. Chang, H.H. Minimum stream power and river channel patterns. J. Hydrol. 1979, 41, 303-327. [CrossRef]

6. Church, M. Geomorphic thresholds in riverine landscapes. Freshwater Biol. 2002, 47, 541-557. [CrossRef]

7. Zaimes, G.N.; Schultz, R.C. Riparian land-use impacts on bank erosion and deposition of an incised stream in north-central Iowa, USA. Catena 2015, 125, 61-73. [CrossRef]

8. Konsoer, K.M.; Rhoads, B.L.; Langendoen, E.J.; Best, J.L.; Ursic, M.E.; Abad, J.D.; Garcia, M.H. Spatial variability in bank resistance to erosion on a large meandering, mixed bedrock-alluvial river. Geomorphology 2016, 252, 80-97. [CrossRef]

9. Stott, T. A comparison of stream bank erosion processes on forested and moorland streams in the Balquhidder Catchments, central Scotland. Earth Surf. Process. Landf. 1997, 22, 383-399. [CrossRef]

10. Leopold, L.B. River Channel Change with Time: An Example. GSA Bull. 1973, 84, 1845-1860. [CrossRef]

11. Lewin, J.; Manton, M.M.M. Welsh floodplain studies: The nature of floodplain geometry. J. Hydrol. 1975, 25, 37-50. [CrossRef]

12. Wood, A.L.; Simon, A.; Downs, P.W.; Thorne, C.R. Bank-toe processes in incised channels: The role of apparent cohesion in the entrainment of failed bank materials. Hydrol. Process. 2001, 15, 39-61. [CrossRef]

13. Lewin, J.; Ashworth, P.J. Defining large river channel patterns: Alluvial exchange and plurality. Geomorphology 2014, 215, 83-98. [CrossRef]

14. Lewin, J. Initiation of bed forms and meanders in coarse-grained sediment. GSA Bull. 1976, 87, $281-285$. [CrossRef]

15. Hickin, E.J. Vegetation and river channel dynamics. Can. Geogr./Le Géogr. Can. 1984, 28, 111-126. [CrossRef]

16. Czech, W.; Radecki-Pawlik, A.; Wyżga, B.; Hajdukiewicz, H. Modelling the flooding capacity of a Polish Carpathian river: A comparison of constrained and free channel conditions. Geomorphology 2016, 272, $32-42$. [CrossRef]

17. Gilvear, D.; Winterbottom, S.; Sichingabula, H. Character of channel planform change and meander development: Luangwa River, Zambia. Earth Surf. Process. Landf. 2000, 25, 421-436. [CrossRef]

18. Nicoll, T.J.; Hickin, E.J. Planform geometry and channel migration of confined meandering rivers on the Canadian prairies. Geomorphology 2010, 116, 37-47. [CrossRef]

19. Dépret, T.; Gautier, E.; Hooke, J.; Grancher, D.; Virmoux, C.; Brunstein, D. Causes of planform stability of a low-energy meandering gravel-bed river (Cher River, France). Geomorphology 2017, 285, 58-81. [CrossRef]

20. Couper, P.R.; Maddock, I.P. Subaerial river bank erosion processes and their interaction with other bank erosion mechanisms on the River Arrow, Warwickshire, UK. Earth Surf. Process. Landf. 2001, 26, 631-646. [CrossRef] 
21. Rinaldi, M.; Darby, S.E. Modelling river-bank-erosion processes and mass failure mechanisms: Progress towards fully coupled simulations. In Developments in Earth Surface Processes (Gravel-Bed Rivers VI: From Process Understanding to River Restoration; Vol. 11); Habersack, H., Piégay, H., Rinaldi, M., Eds.; Elsevier: Amsterdam, The Netherlands, 2007; pp. 213-239.

22. Fischenich, J.C. Effects of Riprap on Riverine and Riparian Ecosystems; ERDCIEL TR-03-4; U.S. Army Engineer Research and Development Center: Vicksburg, MS, USA, 2003; pp. 1-63.

23. Kiss, T.; Fiala, K.; Sipos, G. Alterations of channel parameters in response to river regulation works since 1840 on the Lower Tisza River (Hungary). Geomorphology 2008, 98, 96-110. [CrossRef]

24. Li, L.; Lu, X.; Chen, Z. River channel change during the last 50 years in the middle Yangtze River, the Jianli reach. Geomorphology 2007, 85, 185-196. [CrossRef]

25. Leopold, L.B. Downstream change of velocity in rivers. Am. J. Sci. 1953, 251, 606-624. [CrossRef]

26. Curtis, K.E.; Renshaw, C.E.; Magilligan, F.J.; Dade, W.B. Temporal and spatial scales of geomorphic adjustments to reduced competency following flow regulation in bedload-dominated systems. Geomorphology 2010, 118, 105-117. [CrossRef]

27. Bridge, J.S.; Jarvis, J. Flow and sedimentary processes in the meandering river South Esk, Glen Clova, Scotland. Earth Surf. Process. Landf. 1976, 1, 303-336. [CrossRef]

28. Stoesser, T.; Ruether, N.; Olsen, N.R.B. Calculation of primary and secondary flow and boundary shear stresses in a meandering channel. Adv. Water Resour. 2010, 33, 158-170. [CrossRef]

29. Engel, F.L.; Rhoads, B.L. Velocity profiles and the structure of turbulence at the outer bank of a compound meander bend. Geomorphology 2017, 295, 191-201. [CrossRef]

30. Tang, X.; Knight, D.W. A general model of lateral depth-averaged velocity distributions for open channel flows. Adv. Water Resour. 2008, 31, 846-857. [CrossRef]

31. Wyzga, B. River response to channel regulation: Case study of the Raba river, Carpathians, Poland. Earth Surf. Process. Landf. 1993, 18, 541-556. [CrossRef]

32. Johnson, W.C. Equilibrium response of riparian vegetation to flow regulation in the Platte river, Nebraska. Regul. River 1997, 13, 403-415. [CrossRef]

33. Surian, N. Channel changes due to river regulation: The case of the Piave River, Italy. Earth Surf. Process. Landf. 1999, 24, 1135-1151. [CrossRef]

34. Kiss, T.; Andrási, G.; Hernesz, P. Morphological alteration of the Drava as the result of human impact. AGD Landsc. Environ. 2011, 5, 58-75.

35. Kiss, T.; Blanka, V.; Sipos, G. Morphometric change due to altered hydrological conditions in relation with human impact, River Hernád, Hungary. Z. für Geomorphol. Suppl. Issues 2009, 53, 197-213. [CrossRef]

36. Amissah, G.J.; Kiss, T.; Fiala, K. Morphological Evolution of the Lower Tisza River (Hungary) in the 20th Century in Response to Human Interventions. Water 2018, 10, 884. [CrossRef]

37. Nelson, N.C.; Erwin, S.O.; Schmidt, J.C. Spatial and temporal patterns in channel change on the Snake River downstream from Jackson Lake dam, Wyoming. Geomorphology 2013, 200, 132-142. [CrossRef]

38. Provansal, M.; Dufour, S.; Sabatier, F.; Anthony, E.J.; Raccasi, G.; Robresco, S. The geomorphic evolution and sediment balance of the lower Rhône River (southern France) over the last 130years: Hydropower dams versus other control factors. Geomorphology 2014, 219, 27-41. [CrossRef]

39. Kiss, T. Changing dynamics of fluvial processes due to human impact equilibrium and sensitivity in a fluvial context. D.Sc. Dissertation, Hungarian Academy of Sciences, Szeged, Hungary, 2014. (In Hungarian).

40. Kasse, C.; Bohncke, S.J.P.; Vandenberghe, J.; Gábris, G. Fluvial style changes during the last glacial-interglacial transition in the middle Tisza valley (Hungary). Proc. Geol. Assoc. 2010, 121, 180-194. [CrossRef]

41. Lászlóffy, W. The Tisza River: Water Development and Management in Its River Basin; Akadémiai Kiadó: Budapest, Hungary, 1982.

42. Mezősi, G. The Physical Geography of Hungary; Springer: Basel, Switzerland, 2009; pp. 121-164. ISBN 978-3-319-45183-1.

43. Sipos, G.; Kiss, T.; Fiala, K. Morphological alterations due to channelization along the lower Tisza and Maros Rivers (Hungary). Geogr. Fiscica Din. Quat. 2007, 30, 239-247.

44. Amissah, G.J.; Kiss, T.; Fiala, K. Centurial changes in the depth conditions of a regulated river: Case study of the Lower Tisza River, Hungary. J. Environ. Geogr. 2017, 10, 41-51. [CrossRef]

45. Dunka, S.; Fejér, L.; Vágás, I. The New Conquest: History of the Regulation of Tisza River; Vízügyi Múzeum és Levéltár: Budapest, Hungary, 1996. (In Hungarian) 
46. Lóczy, D.; Kis, É.; Schweitzer, F. Local flood hazards assessed from channel morphometry along the Tisza River in Hungary. Geomorphology 2009, 113, 200-209. [CrossRef]

47. Schweitzer, F. Strategy or disaster: Flood prevention related issues and actions in the Tisza River Catchment. Hung. Geogr. Bull. 2009, 58, 3-17.

48. Csoba, J. Basic idea and Methods of Modern River Management; Water Science Research Institute: Budapest, Hungary, 1973. (In Hungarian)

49. Kiss, T.; Blanka, V.; Andrási, G.; Hernesz, P. Extreme Weather and the Rivers of Hungary: Rates of Bank Retreat. In Geomorphological Impacts of Extreme Weather; Loczy, D., Ed.; Springer: Dordrecht, The Netherlands, 2013; pp. 83-98.

50. Klingemann, P.C.; Kehe, S.M.; Owusu, Y.A. Streambank Erosion Protection and Channel Scour Manipulation Using Rockfill Dikes and Gabions; Water Resources Research Institute Project Number 6864-09:176; Oregon State University: Corvallis, OR, USA, 1984.

51. Robert, A. Characteristics of velocity profiles along riffle-pool sequences and estimates of bed shear stress. Geomorphology 1997, 19, 89-98. [CrossRef]

52. Thompson, D.M. Pool-Riffle Sequences. In Reference Module in Earth Systems and Environmental Sciences; Elsevier: Amsterdam, The Netherlands, 2018.

53. Somogyi, S. River-section types of the Hungarian river network. Földrajzi Közlemények 1983, 31, $220-229$. (In Hungarian)

54. Wyżga, B.; Zawiejska, J.; Radecki-Pawlik, A. Impact of channel incision on the hydraulics of flood flows: Examples from Polish Carpathian rivers. Geomorphology 2016, 272, 10-20. [CrossRef]

(C) 2019 by the authors. Licensee MDPI, Basel, Switzerland. This article is an open access article distributed under the terms and conditions of the Creative Commons Attribution (CC BY) license (http://creativecommons.org/licenses/by/4.0/). 